\title{
A Survey of Phytophthora spp. Associated with Abies in U.S. Christmas Tree Farms
}

\author{
K. M. McKeever and G. A. Chastagner, Department of Plant Pathology, Washington State University Puyallup Research and Extension
} Center, Puyallup 98371

\begin{abstract}
McKeever, K. M., and Chastagner, G. A. 2016. A survey of Phytophthora spp. associated with Abies in U.S. Christmas tree farms. Plant Dis. 100:11611169.

Multiple Phytophthora spp. are known to cause Phytophthora root rot (PRR) on Abies spp. Varying host susceptibilities and regional differences in Phytophthora community compositions complicate disease avoidance and management for Christmas tree growers and conifer nurseries. A survey of 32 Christmas tree farms in seven U.S. states representing four major Christmas tree production regions was conducted in 2012 to 2013 to characterize current distributions of root-rotting Phytophthora spp. and assess host responses to disease. Symptomatic tissues from lesion margins on roots and crowns were plated on selective medium to recover Phytophthora Cultures were identified by DNA sequencing of the nuclear internal

transcribed spacer and mitochondrial cox I regions. Phytophthora cambivora was the prominent PRR species in western Washington and Oregon, while $P$. cinnamomi was prevalent in California and North Carolina. In the eastern United States, the undescribed $P$. taxon kelmania was isolated frequently and was capable of killing fir species considered tolerant of PRR Completion of Koch's postulates confirmed pathogenicity of 12 previously unpublished Phytophthora-fir associations that were observed during this survey. Information regarding regional pathogen species prevalence and relative host susceptibilities will facilitate disease prevention by improving site management strategies for Phytophthora suppression.
\end{abstract}

Root and collar rot of seedlings and trees caused by Phytophthora is familiar to growers in the conifer nursery and Christmas tree industries. True fir trees (Abies spp.) are common hosts of Phytophthora, and species such as noble fir (Abies procera Rehder) and Fraser fir (A. fraseri (Pursh) Poir.) are particularly susceptible to Phytophthora root rot (PRR) (Benson and Grand 2000; Chastagner and Benson 2000; Chastagner et al. 1990a,b; Hamm and Hansen 1982; Kuhlman and Hendrix 1963). Aboveground symptoms associated with PRR include resinous stem cankers, cambial lesions with distinct margins, branch flagging, diminished apical leader growth, wilting of succulent spring foliage, foliar chlorosis, and a characteristic reddening of the needles with advanced infection and senescence (Chastagner and Benson 2000; Chastagner et al. 1995; Oh and Hansen 2007). Phytophthora infections on roots result in a cortical rot characterized by darkened tissue and sloughing root bark. On some host species, heavy root infections can spread through the vascular system, leading to subrhytidomal stem lesions (Chastagner and Benson 2000; Cooley et al. 1985; Oh and Hansen 2007). Senescence and mortality can occur from coalescence of cambial necrosis resulting in girdling of the tree or loss of water and nutrient acquisition due to reduced capacity of the root system (Chastagner et al. 1990a).

Phytophthora spp. cause disease on an array of true fir species in the major Christmas tree production areas of the United States, as well as in parts of Europe, including Scandinavia. Fraser fir is susceptible to infection by Phytophthora cinnamomi Rands, $P$. cactorum (Lebert \& Cohn) J. Schröt, P. citricola Sawada, P. drechsleri Tucker, and P. plurivora T. Jung \& T. I. Burgess (Adams and Bielenin 1988; Benson et al. 1976; Chastagner and Benson 2000; Frampton and Benson 2004; Jung and Burgess 2009; Kuhlman and Hendrix

\section{Corresponding author: K. M. McKeever; E-mail: kmmckeev@wsu.edu}

PPNS number 0694, Department of Plant Pathology, College of Agricultural, Human, and Natural Resources Sciences, Agricultural Research Center, Hatch Project Number WNP00388, Washington State University, Pullman 99164-6430

Accepted for publication 21 January 2016.

http://dx.doi.org/10.1094/PDIS-08-15-0939-RE

(C) 2016 The American Phytopathological Society
1963). Balsam fir (A. balsamea (L.) Mill.) and white fir (A. concolor (Gordon) Lindley ex Hildebrand) have been demonstrated to be hosts for P. cinnamomi, $P$. citricola, and P. cactorum (Adams and Bielenin 1988; Grand 1985; Kenerley and Bruck 1981). Nordmann fir (A. nordmanniana (Steven) Spach.) has been infected by P. cinnamomi in the United States and also with $P$. inundata Brasier, Sánch. Hern. \& S. A. Kirk in Norway and P. niederhauserii Z. G. Abad \& J. A. Abad in Hungary (Abad et al. 2014; Grand 1985; Talgø et al. 2007). Noble fir is particularly vulnerable to PRR, with disease reported to be caused by $P$. cambivora (Petri) Buisman, $P$. cactorum, $P$. cryptogea Pethybr. \& Laff., P. cinnamomi, P. megasperma Drechsler, P. gonapodyides (H. E. Petersen) Buisman, and P. citricola (Adams and Bielenin 1988; Chastagner et al. 1990a, 1995; Hamm and Hansen 1982; Talgø et al. 2006). Other true fir that have been shown to be susceptible to a complex of Phytophthora spp. include subalpine fir (A. lasiocarpa (Hooker) Nuttall), silver fir (A. amabilis Douglas ex J. Forbes), Shasta red fir (A. magnifica A. Murray var. shastensis Lemmon), and grand fir (A. grandis (Douglas ex D. Don) Lindley) (Chastagner et al. 1990a; Hamm and Hansen 1982; Talgø et al. 2007). Additional Phytophthora spp. that have been implicated in the PRR complex on true fir and Douglas-fir (Pseudotsuga menziesii (Douglas) ex D. Don) include Phytophthora pseudotsugae Hamm \& E. M. Hansen, P. sansomeana E. M. Hansen \& Reeser, and the yet undescribed $P$. taxon kelmania (Abad et al. 2002; Hamm and Hansen 1983; Hansen et al. 2009). The species structures of Phytophthora communities appear to vary regionally in accordance with distribution of hosts and environmental conditions such as soil moisture and temperature. Disease is favored by abundant soil moisture common with poorly drained soils or excessive irrigation (Chastagner et al. 1995; Cooley et al. 1985; Erwin and Ribeiro 1996; Hamm et al. 1984). Disease management can be complicated by the large number of Abies hosts that are affected and the variety of different species of Phytophthora that can cause disease, resulting in high losses in conifer nursery and Christmas tree operations.

Much of the previous literature regarding PRR on Abies is comprised of surveys that were initiated in response to PRR outbreaks in nurseries or farms, and only a few studies have purposely surveyed a number of geographic locations for the purpose of characterizing community structures and regional variation (Hamm and Hansen 1982, 1983; Kenerley and Bruck 1981; McCain and Scharpf 1986; Shew and Benson 1981). In the northwestern United States, a 1976 survey 
of conifer nurseries and regeneration sites in Oregon and Washington established that $P$. cinnamomi, $P$. drechsleri, and P. cryptogea were causing mortality of Douglas-fir seedlings and orchard trees but this study did not survey Abies spp. (Pratt et al. 1976). A survey of 16 Oregon and Washington bare-root conifer nurseries in 1979 yielded $P$. drechsleri, $P$. megasperma, $P$. cryptogea, $P$. cactorum, and $P$. cinnamomi, but made no mention of the host species from which these Phytophthora spp. were isolated (Hansen et al. 1979). A 1990 study by Chastagner et al. (1990a) found P. cambivora, $P$. cryptogea, $P$. cinnamomi, and a $P$. gonapodyides-like isolate in a survey of four noble fir plantations in Oregon. This study was followed up 5 years later with a survey of 30 Oregon and Washington noble fir Christmas tree plantations, where at least seven Phytophthora spp. were found causing root and stem canker symptoms on 48 trees in 20 of the 30 sampled plantations (Chastagner et al. 1995). This study revealed the dominance of $P$. cambivora and $P$. megasperma on noble fir, and also presented evidence of rot caused by $P$. cactorum, $P$. citricola, $P$. cinnamomi, and $P$. gonapodyides (Chastagner et al. 1995). Grand \& Lapp (1974) tracked fir mortality in Christmas tree plantations in western North Carolina during a 10 -year period. During this time, Fraser fir was the only host sampled from 14 plantations and P. cinnamomi was the only Phytophthora sp. identified causing PRR (Grand and Lapp 1974). A larger survey performed in 2000 by Benson and Grand (2000) surveyed 58 statewide North Carolina Christmas tree farms and 16 nursery transplant beds, sampling from $>1,000$ Fraser fir seedlings and older, established trees. Over $90 \%$ of the mortality appeared to be caused by $P$. cinnamomi but $P$. cactorum and $P$. drechsleri were also found. In 1988, Adams and Bielenin (1988) observed $P$. cactorum and $P$. citricola on balsam, noble, white, Fraser, and Douglas-fir seedlings in various conifer nurseries on the lower peninsula of Michigan. More recently, a general survey of 30 nursery, greenhouse, and landscape sites in Iowa, Michigan, Ohio, and Indiana revealed 13 Phytophthora spp. affecting a variety of horticultural hosts including Abies spp.; however, no details were provided regarding which species of fir were sampled or the identities or frequency of Phytophthora spp. that were recovered from fir (Leonberger et al. 2013).

PRR is one of the most important issues affecting U.S. true fir Christmas tree producers (Chastagner and Benson 2000; Frampton and Benson 2012; Talgø et al. 2006, 2007). Increases in consumer demand for desirable true fir Christmas trees has resulted in a present-day cut-Christmas tree industry worth more than \$300 million annually (United States Department of Agriculture National Agricultural Statistics Service 2014). As of 2012, more than 300,000 acres of land were dedicated to Christmas tree production in the United States, and losses from PRR limit the ability of growers to expand plantings of highly desirable species such as noble and Fraser fir (Benson and Grand 2000; Benson et al. 2006; United States Department of Agriculture National Agricultural Statistics Service 2014). Additionally, greenhouse data indicate variability in host resistance dependent on the Phytophthora spp. present. Inoculation trials performed at Washington State University (unpublished data) found less than $30 \%$ damage on Abies spp. such as Turkish, Nordmann, white, and balsam fir caused by $P$. cambivora and $P$. pini, which occur commonly in the Pacific Northwest (PNW). In contrast, trials performed by researchers at North Carolina State University demonstrated mortality percentages as high as 60 to $80 \%$ in Turkish and Nordmann fir, respectively, and nearly $100 \%$ in white and balsam fir when exposed to $P$. cinnamomi, which is prevalent in southeastern growing regions (Frampton and Benson 2012). For these reasons, a clearer understanding of current regional Phytophthora community structures and host reactions to PRR is needed. By clarifying the dynamics of the PRR system, researchers will be better equipped to investigate methods to exploit host resistance for PRR abatement and provide proper recommendations to growers about which host species will be most successful in their local areas. This article summarizes the results of a survey of root-rotting Phytophthora in U.S. Christmas tree plantations in order to characterize regional Phytophthora species diversity and observe geographic differences in the susceptibility of various Abies spp. Additionally, there was an opportunity to explore the possibility for potential parallels between current pathogen community compositions and an increased diversity in the number of sources providing planting material for the Christmas tree industry.

Throughout the course of the survey, it was acknowledged that several of the Abies-Phytophthora combinations that were observed were previously unreported in the literature, prompting motivation to complete Koch's postulates for each novel interaction in order to provide proof of pathogenicity of these Phytophthora spp. on their observed hosts and establish new disease reports.

\section{Materials and Methods}

Study sites. Survey efforts were concentrated in five major U.S. Christmas tree production regions during a 2-year period from 2012 to 2013. The PNW region included 12 Christmas tree plantations in western Washington, 6 in western Oregon, and 3 sites in northern Idaho. The western region included five sites in northern California. The northeastern region was represented by two sites in Connecticut and one in New York, while the southeastern region comprised four sites in North Carolina. Archived Phytophthora cultures from Michigan and Wisconsin were included to represent farms in the Great Lakes region. Cultures from Michigan were collected in 2005 by researchers at Michigan State University at an undisclosed number of sites in five counties. Cultures from Wisconsin were collected over a 3-year period from 2010 to 2013 by Wisconsin Department of Agriculture, Division of Trade and Consumer Protection personnel from various sites in three counties. In general, samples in Michigan were isolated from the soil surrounding Fraser fir seedlings in a transplant bed, whereas the Wisconsin collection came directly from the roots of species including Fraser, balsam, and Canaan fir.

Isolation methods. Diseased trees were recognized by visual detection of common root rot symptoms, including flagging lower branches, stunted leader growth, wilting shoots, and chlorotic and necrotic foliage. In many instances, large cinnamon-brown bole lesions could be located by scraping back the bark around dead branches on the lower stems of noble and Fraser fir. Mature (1.5 to $2 \mathrm{~m}$ ) trees were sampled either by exposing necrotic stem lesions or by uprooting entire trees and exposing rotten roots. Pieces of woody tissue $\left(1 \mathrm{~cm}^{2}\right)$ from the margins of stem and root lesions were sampled for recovery of Phytophthora spp. In the cases of 1- to 3-year-old seedlings from field and transplant beds, seedlings were uprooted and 10 symptomatic root tips were removed for plating.

All diseased plant tissues were surface sterilized in a $10 \%$ solution of $8.25 \% \mathrm{NaClO}$ in sterile deionized (DI) water for $30 \mathrm{~s}$, rinsed twice in fresh sterile DI water, and briefly dried before plating into PARPH-clarified V8 (cV8) semiselective medium (15 g of Difco agar, $33 \mathrm{ml}$ of clarified V8 juice, $10 \mathrm{mg}$ of Delvocid salt [50\% pimaricin], $250 \mathrm{mg}$ of sodium ampicillin, $10 \mathrm{mg}$ of rifampicin sodium salt, $67 \mathrm{mg}$ of Terraclor [75\% pentachloronitrobenzene], and $50 \mathrm{mg}$ of hymexazol in 1 liter of water). Cultures were allowed to incubate at $19^{\circ} \mathrm{C}$ in the dark for 3 to 5 days before being examined under a compound microscope to identify putative Phytophthora spp. emanating from the tissue. Any suspected Phytophthora cultures were subcultured from the isolation plate onto fresh PARPH-cV8 and subsequently onto unamended cV8 medium. Cultures were microscopically examined during a 7- to 10-day period for preliminary morphological classification to substantiate identity as Phytophthora spp. prior to molecular identification. To encourage sporangia production for identification purposes, agar plugs ( $5 \mathrm{~mm}$ in diameter) from a given culture were flooded with nonsterile soil solution ( $15 \mathrm{~g}$ of field soil dissolved in 1 liter of DI water and vacuum filtered through Whatman number 1 filter paper) and incubated at room temperature overnight under fluorescent light (Jeffers and Aldwinckle 1987). A subset of resulting sporangia were scored for shape, average size, caducity, and papilla formation. Gametangia formation and presence or absence of spores on solid media and soil solution were also noted.

DNA extraction, polymerase chain reaction, and species identification. To compliment morphological identification, the 
internal transcribed spacer (ITS) region of the nuclear ribosomal DNA and the cytochrome c oxidase I ( $\operatorname{cox}$ I) region of the mitochondrial DNA were amplified and sequenced for molecular verification. Phytophthora cultures were prepared for DNA extraction by growing for 3 to 5 days on sterile cellophane rounds layered over fresh plates of PARPH-cV8 media. This process encouraged hyphae to grow on top of the cellophane layer in order to minimize inclusion of agar medium into the reaction tubes during extraction. DNA was extracted using the Qiagen DNeasy Plant Mini Kit (Qiagen, Inc., Valencia, CA) following the manufacturer's instructions. DNA and polymerase chain reaction (PCR) products were stored for the short term $(<1$ month $)$ at $4{ }^{\circ} \mathrm{C}$. ITS regions were amplified using ITS6F and ITS4R primers (Cooke et al. 2000). PCR conditions for ITS amplification included initial denaturation at $94^{\circ} \mathrm{C}$ for $3 \mathrm{~min}$; followed by 35 cycles of $30 \mathrm{~s}$ at $94^{\circ} \mathrm{C}$, $30 \mathrm{~s}$ at $55^{\circ} \mathrm{C}$, and $1 \mathrm{~min}$ at $72^{\circ} \mathrm{C}$; with a subsequent $10 \mathrm{~min}$ at $72^{\circ} \mathrm{C}$. The $\operatorname{cox} \mathrm{I}$ region was amplified using the OomCoxILevup and OomCoxI-Levlo primers (Robideau et al. 2011). PCR conditions for cox I amplification included initial denaturation at $94^{\circ} \mathrm{C}$ for $10 \mathrm{~min}$; followed by 35 cycles of $30 \mathrm{~s}$ at $94^{\circ} \mathrm{C}$, $30 \mathrm{~s}$ at $56^{\circ} \mathrm{C}$, and $1 \mathrm{~min}$ at $72^{\circ} \mathrm{C}$; with a subsequent $10 \mathrm{~min}$ at $72^{\circ} \mathrm{C}$. PCR products were purified by mixing $2 \mu \mathrm{l}$ of ExoSAPIT (Affymetrix, Santa Clara, CA) with $5 \mu$ l of PCR product and following the manufacturer's thermocycler protocol of $15 \mathrm{~min}$ at $37^{\circ} \mathrm{C}$ and $15 \mathrm{~min}$ at $80^{\circ} \mathrm{C}$. After purification, diluted $3.125 \mu \mathrm{M}$ forward primer was added to the PCR products prior to sequencing by GENEWIZ (South Plainfield, NJ).

Consensus sequences were constructed from forward and reverse sequence data using the alignment tool in the Molecular Evolutionary Genetics Analysis (MEGA), version 6.0 program (Center for Evolutionary Medicine and Informatics, Tempe, AZ). These sequences were submitted to search for homology among published sequences using the National Center for Biotechnology Information GenBank BLASTn and Phytophthoradb.org databases (Benson et al. 2011; Bienapfl and Balci 2014; Park et al. 2008). Database sequence results were examined against queried sequences for base pair agreement and nucleotide homology of at least $99 \%$ for species affirmation (Moralejo et al. 2009; Parke et al. 2014; Schwingle et al. 2007; Yakabe et al. 2009). In cases where ITS was noninformative (multiple matching sequences), the cox I sequence served as a second locus for proper identification. Species identities assigned by sequence matches were verified by ensuring that morphological characteristics were consistent with published literature (Erwin and Ribeiro 1996). The MEGA 6.0 tree explorer tool was used to construct a maximumlikelihood phylogram using 1,000 bootstrap replicates to compare ITS consensus sequences with published sequences for verification of species identification and clarification of taxonomic standing (Fig. 1). The phylogeny was constructed using a subset of isolates that included at least one isolate per Phytophthora sp. from each host in each state.

Koch's postulates. Root inoculations for completion of Koch's postulates were carried out to prove pathogenicity on 12 novel combinations of Phytophthora spp. on fir. One-year-old seedlings of four species of fir and 2-year-old seedlings of two species of fir were inoculated in a greenhouse root-inoculation experiment with a varying combination of Phytophthora spp. (Table 1). One-year-old plug seedlings (P-0 stock) of Fraser fir, Nordmann fir, and Canaan fir (A. balsamea var. phanerolepis Fern.) were obtained from Lawyer Nursery (Olympia, WA) along with 1-year-old bare-root (1-0) seedlings of grand fir. Two-year-old (P-1 stock) Turkish fir (A. bornmuelleriana Mattf.) and Trojan fir (A. equi-trojani (Asch. \& Sint. ex Boiss) Mattf.) were started as plugs for the first year at the Kintigh Mountain Home Ranch (Springfield, OR), and subsequently transplanted into 1.5-liter treepots (Stuewe \& Sons, Tangent, OR) to be maintained outdoors for the second year at the Washington State University Puyallup Research and Extension Center. Phytophthora isolates were grown for 21 days on sterilized long-grain white rice in 2-mil polypropylene, gusseted spawn bags with microporous filter patches (Fungi Perfecti, Shelton, WA). Rice was prepared by autoclaving rice grains three times over the course of 3 separate days in ca. 3:4 ratio of rice grain:sterile DI water. Bags were inoculated by seeding with 10 plugs ( $7 \mathrm{~mm}$ in diameter) taken from the edges of 5-day-old pure cultures grown on cV8 medium in a sterile laminar flow hood. Rice grains for control treatments were prepared in the same way but seeded with plugs from an uncolonized plate. All bags were sealed with an impulse sealer. Spawn bags were maintained on a benchtop at room temperature for 21 days and agitated every other day to encourage uniform colonization.

Prior to inoculation, rice grains were pulverized in a kitchen-grade food processor and screened through a $2-\mathrm{mm}$ (number 10) soil sieve. Rice grains were incorporated into a commercially available potting mix (Gardener's Professional Secret; Specialty Soils, Covington, WA) at a rate of $4 \%$ (rice at $0.04 \mathrm{~g} / \mathrm{g}$ of soil). All nursery soil was washed away from the root balls of seedlings and they were subsequently planted into Ray Leach SC10 Super Cone-tainers (Stuewe $\&$ Sons) using infested potting media. There were five replicates for each Abies-Phytophthora combination and each control treatment. Seedlings were maintained at $21^{\circ} \mathrm{C}$ and exposed to a 12 -h photoperiod under $400-\mathrm{W}$ high-pressure sodium greenhouse lights for 8 weeks. Light levels were measured using the Quantum meter on a LiCor LI-1600 Steady State Porometer (LiCor, Lincoln, NE) and averaged about $178 \mu \mathrm{mol} \mathrm{s}^{-1} \mathrm{~m}^{-2}$ at full intensity. Immediately following inoculation, seedlings were subject to two 45-min drenches within a $24-\mathrm{h}$ period via overhead irrigation at a rate of $0.25 \mathrm{ml} / \mathrm{min}$ to promote the saturated conditions that are conducive to PRR. Subsequent irrigation was administered twice daily for 10-min periods, once in the morning and once in the evening, for the duration of the experiment.

At the end of the incubation period, seedlings were removed from the cones and the infested potting medium was washed from the roots. The extent of root rot was rated by teasing apart the roots and visually estimating the proportion of symptomatic root tips on a scale of 0 to 5 , where $0=<10 \%$ necrotic root tips and $1=10$ to $25 \%, 2=25$ to $50 \%, 3=50$ to $75 \%, 4=75$ to $90 \%$, and $5=>90 \%$ necrotic roots (Table 1). Ten symptomatic root tips from each tree were plated onto PARPH-cV8 selective medium to confirm recovery of the pathogen. All resulting Phytophthora cultures were subcultured to unamended cV8 media upon reisolation from symptomatic roots, and were matched to the original isolate by morphology and ITS sequence.

\section{Results}

Survey sites. Of the 32 Christmas tree plantations visited in the PNW, western, northeastern, and southeastern regions of the United States, Phytophthora spp. were recovered from a total of 36 fir trees in 24 sites, yielding 105 total isolates (Table 2). Michigan cultures were isolated from the soil surrounding seven host trees in five counties and Wisconsin cultures were received from five host trees in three counties, comprising 12 total Phytophthora isolates from the Great Lakes Region (Table 2). The maximum-likelihood phylogram that was constructed to infer confidence in species identifications verified that collected isolate identifications were statistically similar to known reference sequences and provided information about the distribution of Phytophthora clade groups in U.S. Christmas tree farms (Fig. 1).

P. cambivora was the most commonly isolated species in the PNW region represented by western Washington, western Oregon, and northern Idaho. Nearly $90 \%$ of the sampled trees in Oregon and Washington were mature noble fir (7 to 10 years old), on which disease was easily identified by flagging lower branches and large bole cankers. The majority of the samples from noble fir were isolated from the lesion margins between healthy and necrotic tissues on the lower stems and crowns. A single $P$. megasperma isolate was recovered from the roots of a 2-year-old transplanted noble fir in a Washington site that is commonly flooded from a nearby retention pond that previous sampling has indicated harbors $P$. megasperma. Also in Washington, diseased Fraser fir seedlings in a nursery transplant bed yielded putative $P$. pseudosyringae T. Jung \& Delatour but Koch's postulates have not yet been completed to verify this interaction. A grand fir sample from southwestern Oregon was found to have aerial infections caused by $P$. gonapodyides on lower branches and twigs, becoming the only species aside from $P$. cambivora 
recovered from Oregon. Host species sampled in Idaho included concolor (white) fir and grand fir, but collections yielded only a single isolate of $P$. megasperma from the roots of a diseased grand fir in a stand of mature dead and dying trees near the base of a slope at one farm.
In the western region, $P$. cinnamomi was the only Phytophthora sp. isolated from root tissues of a variety of hosts at several northern California farms. The hosts sampled in California included a diversity of age classes and species, including the exotic Trojan and

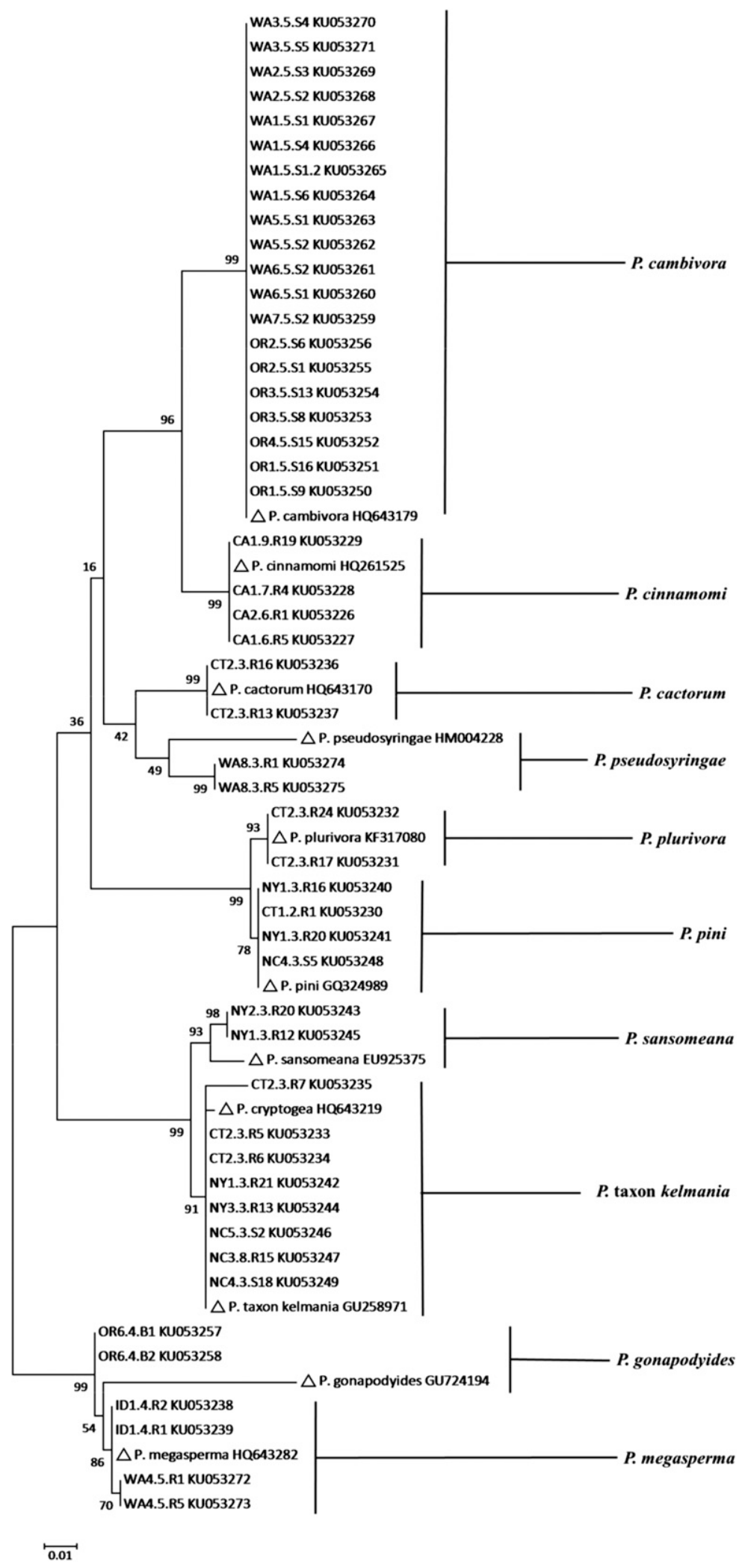

Fig. 1. Maximum-likelihood tree using ribosomal DNA internal transcribed spacer (ITS) sequences showing phylogenetic relationships between Phytophthora isolates collected during this survey and reference Phytophthora sequences obtained from GenBank. Numbers near nodes represent the percentage of trees in which the associated taxa clustered together during bootstrap analysis performed with 1,000 replications. The subset of isolates represented in the phylogeny included at least one isolate per Phytophthora sp. from each host in each state. A triangle $(\Delta)$ indicates reference sequences for the ITS 1 region from validated isolates that have been accessed via GenBank from the World Phytophthora Collection or the American Type Culture Collection. 
Nordmann firs and native concolor fir. Other symptomatic trees sampled in California included Shasta red fir and Turkish fir, but sampling from these individuals did not yield Phytophthora spp.

In the northeastern region, $P$. taxon kelmania was the most frequently isolated species from both Connecticut and New York. The second most commonly isolated species was $P$. pini, followed by $P$. plurivora and $P$. sansomeana. $P$. cactorum was isolated only once from a single symptomatic Fraser fir seedling in a Connecticut transplant bed. The predominant fir species sampled in the northeastern region was Fraser fir, with trees of all age classes proving to be viable hosts for Phytophthora spp.

$P$. taxon kelmania was also the most commonly isolated Phytophthora sp. in North Carolina, followed closely by the historically predominant $P$. cinnamomi. These two species were found on Fraser fir but were also commonly isolated from Turkish and Trojan fir trees planted at multiple sites in northern North Carolina. Additional Phytophthora spp. isolated from Fraser fir in North Carolina include $P$. pini and P. cryptogea.

Cultures from collections in Michigan and Wisconsin included isolates of species that were not observed in other regions, including P. europaea E. M. Hansen \& T. Jung and P. nicotianae Breda de Haan.

Koch's postulates. The results of these trials provided proof of pathogenicity for many new Phytophthora-Abies combinations (Table 1). Foliar symptoms observed on inoculated seedlings included wilt or necrosis of newly expanding shoots, a failure to break bud, and overall seedling mortality. Visual root rot ratings ranged from a high of 4.8 for $P$. pini on Fraser fir to a low of 2.0 (Table 1). Commonly, some darkened roots were observed on the uninoculated control seedlings, resulting occasionally in ratings that registered as high as a 2.0; however, no foliar symptoms were observed on control seedlings and no Phytophthora spp. were isolated from any darkened root tips of uninoculated seedlings. Phytophthora spp. were reisolated from symptomatic roots on all five of the five inoculated seedlings for each host-pathogen challenge in both trials. All reisolated cultures from inoculated seedlings were consistent in morphology and ITS sequence to the isolates that were originally used for inoculation, confirming pathogenicity of the Phytophthora spp. on their corresponding hosts (Table 1).

\section{Discussion}

Assessments of the diversity in the genus Phytophthora estimate that there are several hundred species, with a large percentage associated with diseases of forest and nursery trees (Brasier 2009). The survey reported here provides insight into the distribution and community structures of the Phytophthora spp. that are affecting Abies spp. in U.S. Christmas tree farms. Regional variation in the occurrence of a particular species of Phytophthora may depend on annual rainfall, median temperatures, and the host species present, but local Phytophthora communities may also be a function of the nurseries that produce the seedlings. It has become common for seed to be contracted to nurseries in distant regions to be grown as containerized seedlings and then distributed back to farms to be transplanted into outdoor beds, resulting in involvement from a greater number of nurseries and packing facilities. The nationwide circulation of conifer nursery stock could be a potential avenue for cultivation and dissemination of root-rotting Phytophthora spp. and may have the capacity to increase or dictate the diversity of Phytophthora spp. present in a particular region. Nursery location may limit the presence of a particular Phytophthora sp.; for example, species that are favored by warm soils may not thrive in nurseries in cooler climates. Thus, the recipient states of seedlings grown in those nurseries may not observe those Phytophthora spp. as often in their plantings. Poor survival of nursery-borne Phytophthora spp. has also been demonstrated when infested seedlings are outplanted from nurseries into locations with uncomplimentary environments (Hansen et al. 1980; Roth and Kuhlman 1966). Conversely, the expansion of plant trade and movement may increase local Phytophthora diversity by introducing species into novel areas conducive to their survival and proliferation. In the current survey, there was a greater diversity of Phytophthora spp. affecting fir in the eastern and central production areas. This may reflect environmental parameters such as large seasonal temperature fluctuations and ample rainfall during the growing season in contrast to the year-round temperate conditions and dry summers experienced in the western regions, but also may be a result of an increased number of nurseries producing Fraser fir for planting in eastern farms.

In western Washington and Oregon, noble fir was the most commonly sampled Abies sp. The observed dominance of P. cambivora on noble fir provided an updated representation of the Phytophthora community on this host. P. cambivora is a pathogen of temperate host species including a variety of deciduous hardwood and fruit trees in the northern latitudes of Europe and the contiguous United States, and is infrequently reported from warmer, drier regions (Day 1938; Erwin and Ribeiro 1996; Mircetich and Matheron 1976; Talgø et al. 2006, Vannini and Vettraino 2001). This species

Table 1. Pathogenicity of Phytophthora spp. found on Abies hosts for the purpose of establishing new disease reports for various locations

\begin{tabular}{|c|c|c|c|c|}
\hline Abies spp. & Phytophthora spp. & Root rot $^{\mathbf{a}}$ & First report $^{\mathbf{b}}$ & GenBank $^{c}$ \\
\hline \multirow[t]{8}{*}{$\overline{\text { Abies fraseri }}$} & Phytophthora cactorum & 3.1 & Connecticut & KU053237 \\
\hline & P. cryptogea & 4.0 & United States & KU053246 \\
\hline & P. kelmania & 4.0 & Connecticut & KU053233 \\
\hline & P. kelmania & 4.0 & New York & KU053242 \\
\hline & P. plurivora & 4.0 & Connecticut & KU053232 \\
\hline & P. pini & 4.8 & North Carolina & KU053248 \\
\hline & P. pini & 4.0 & New York & KU053241 \\
\hline & P. sansomeana & 4.0 & New York & KU053245 \\
\hline A. grandis & P. megasperma & 3.0 & United States & KU053238 \\
\hline A. equi-trojani & P. cinnamomi & 3.0 & United States & KU220612 \\
\hline A. nordmanniana & P. cinnamomi & 3.0 & California & KU053226 \\
\hline A. balsamea var. phanerolepis & P. pini & 2.0 & United States & KU053230 \\
\hline \multirow[t]{2}{*}{ A. bornmuelleriana } & P. cinnamomi & 2.0 & United States & KU220613 \\
\hline & P. kelmania & 2.0 & United States & KU053247 \\
\hline
\end{tabular}

a Average root rot rating. Five replicate seedlings for each Abies-Phytophthora combination were inoculated and grown in a greenhouse for 8 weeks, at which time the extent of root rot was rated by teasing apart the washed roots and visually estimating the proportion of necrotic root tips on a scale of 0 to 5 , where $0=$ $<10,1=10$ to $25,2=25$ to $50,3=50$ to $75,4=75$ to 90 , and $5=>90 \%$ necrotic roots. Two trials were performed. The number listed here is the average root rot rating of the five replicate seedlings over two trials.

b Locations for first reports established via Koch's postulates verification of Phytophthora-Abies interactions observed in this survey. Information on existing first reports was obtained from the Systematic Botany and Mycology Laboratory (SBML) fungus-host database (http://nt.ars-grin.gov/fungaldatabases/fungushost/fungushost.cfm).

${ }^{c}$ GenBank accession numbers for isolates used in these experiments. 
does poorly at temperatures exceeding $30^{\circ} \mathrm{C}$ and is therefore well adapted to the cool, wet conditions in the PNW (Erwin and Ribeiro 1996). The 1990 survey of noble fir in 30 western Washington and Oregon Christmas tree farms by Chastagner et al. (1995) indicated a community of at least seven different species of Phytophthora, dominated by $P$. cambivora, $P$. megasperma, $P$. cryptogea, and $P$. gonapodyides. Although the geographic coverage in the present study was not as comprehensive as the survey by Chastagner et al. (1995), one may speculate that the current lack in diversity of Phytophthora spp. on noble fir, save $P$. cambivora, could reflect changes in the conifer nurseries that grow and provide noble fir stock to growers in the PNW. Historically, a number of United States Forest Service nurseries supplied bare-root noble fir seedlings to growers in Oregon and Washington. Many of these nurseries were established on bottomland river sites prone to flooding events and the saturated soils that are conducive to supporting diverse Phytophthora populations. As the number of these nurseries has decreased, the remaining facilities producing Abies seedlings are generally located on upland and interior sites. Changes in nursery location, as well as improvements in nursery management practices and a shift in production from bare-root to container-grown Abies seedlings, may have contributed to the observed reduction in Phytophthora spp. diversity on noble fir in the last 20 years. In spite of these observations, participating growers in this survey were queried about the origins of their seedlings but, in the breadth of this study, no distinct patterns were evident relating to the sources of planting stock and Phytophthora spp. present.

When PRR was observed on other host species in Washington and Oregon, such as grand and Fraser fir, the diversity of Phytophthora spp. obtained from this region was augmented with the addition of $P$. gonapodyides and $P$. pseudosyringae. $P$. gonapodyides is a constituent of riparian ecosystems and is commonly associated with woody hosts (Blair et al. 2008; Brasier et al. 1993; Kroon et al. 2012). This species, along with P. megasperma, has been isolated from aqueous environments including stream water and retention ponds (Brasier et al. 1993). The aerial $P$. gonapodyides twig infections on grand fir in Oregon and the $P$. megasperma infection on noble fir near a retention pond in Washington may have resulted from irrigation using contaminated water. $P$. pseudosyringae has been described infecting oak species in Europe but is also weakly pathogenic on California bay laurel (Umbellularia californica (Hook. \& Arn.) Nutt), tanoak (Notholithocarpus densiflorus (Hook. \& Arn.) Manos, Cann. \& Oh), and coast live oak (Quercus agrifolia) Nee in the mixed-evergreen forests of northern California and southern Oregon (Jung et al. 2003; Linzer et al. 2006; Murphy and Rizzo 2006; Reeser et al. 2009; Wickland and Rizzo 2006). The detection of this species in a western Washington transplant bed on Fraser fir seedlings may have been the result of an introduction on planting stock because these seedlings were planted into fumigated ground. This occurrence may constitute a new report of this species on fir but Koch's postulates have not yet been performed to confirm pathogenicity.

Preceding this survey, little information was available relating to PRR communities affecting fir in Idaho, and current sampling yielded few isolates. In this production region, there is a large market for PRR-tolerant Pinus and Picea Christmas trees in addition to a small selection of Abies spp. composed mostly of white and grand fir. Because few of the more highly PRR-susceptible species such as noble

Table 2. Phytophthora spp. isolated from Abies tissue or associated soils at Christmas tree farms in 9 U.S. states

\begin{tabular}{|c|c|c|c|c|c|}
\hline Phytophthora spp. & Host & State $^{\mathrm{a}}$ & $N^{\mathbf{b}}$ & Sample ${ }^{c}$ & GenBank $^{\mathbf{d}}$ \\
\hline \multirow[t]{5}{*}{ Phytophthora cactorum } & Abies balsamea & Wisconsin & 1 & Collar & $\mathrm{N} / \mathrm{S}^{*}$ \\
\hline & A. fraseri & Connecticut & 2 & Root & KU053237 \\
\hline & & & & & KU053236 \\
\hline & A. fraseri & Michigan & 2 & Soil & AY995343* \\
\hline & & & & & AY995357* \\
\hline \multirow[t]{24}{*}{ P. cambivora } & A. fraseri & Michigan & 1 & Soil & $\mathrm{N} / \mathrm{S}^{*}$ \\
\hline & A. procera & Oregon & 13 & Stem & KU053250 \\
\hline & & & & & KU053251 \\
\hline & & & & & KU053252 \\
\hline & & & & & KU053253 \\
\hline & & & & & KU053254 \\
\hline & & & & & KU053255 \\
\hline & & & & & KU053256 \\
\hline & & & & & KU220617 \\
\hline & & & & & KU220618 \\
\hline & A. procera & Washington & 20 & Stem, collar & KU053259 \\
\hline & & & & & KU053260 \\
\hline & & & & & KU053261 \\
\hline & & & & & KU053262 \\
\hline & & & & & KU053263 \\
\hline & & & & & KU053264 \\
\hline & & & & & KU053260 \\
\hline & & & & & KU053266 \\
\hline & & & & & KU053267 \\
\hline & & & & & KU053268 \\
\hline & & & & & KU053269 \\
\hline & & & & & KU053270 \\
\hline & & & & & KU053271 \\
\hline & & & & & on next page) \\
\hline
\end{tabular}

a U.S. state where isolate was collected.

b Total number of isolates collected from a particular Abies spp. in a particular state.

c Part of the tree from which a given culture was isolated. Collar $=$ basal bole tissue above and adjacent to the soil line, Root $=$ belowground root tissue, Stem $=$ bole tissue above the collar, and Soil = soil immediately surrounding bole or roots of tree. Tissue samples were obtained from lesion margins demarcating diseased and healthy tissues.

${ }^{\mathrm{d}}$ GenBank accession numbers for sequenced isolates. Not all isolates from the total number collected were sequenced. Many isolates were identified based on morphology to others collected in the same area or from the same tree. $\mathrm{N} / \mathrm{S}=$ not submitted and $*$ indicates culture provided from collaborating researcher. 
and Fraser fir are grown in Idaho farms, there is less disease and it is harder to spot visually. Environmental parameters in this region may also be unfavorable for disease development given extreme summer dryness, general lack of irrigation, and cold winter conditions. This may result in the relegation of PRR outbreaks to only certain years or times of year when the environmental conditions are most conducive to disease development. Broadening the geographic area and seasonal time frame of sampling may provide a more complete picture of Phytophthora communities in Idaho.

The presence of P. cinnamomi on fir in California and North Carolina was expected, because these regions have historically dealt with this pathogen (Benson and Grand 2000; Frampton and Benson 2004, 2012; Garbelotto et al. 2006; Grand and Lapp 1974; Zentmyer 1977). Although $P$. cinnamomi occurs on a variety of hosts over a wide climatic range, it is well adapted to warm conditions and is a pathogen of subtropical plants, including avocado (Persea americana Mill.), pineapple (Ananas comosus L. Merr.), and kiwi fruit (Actinidia chinensis Planch.) in southern California; jarrah trees (Eucalyptus marginata Donn. ex Sm.) in Western Australia; and pine in the southeastern United States and New Zealand (Campbell 1948; Erwin and Ribeiro 1996; Mehrlich 1936; Newhook and Podger 1972; Wager 1942; Zentmyer 1977). In both California and North Carolina, warm soil conditions during much of the year provide temperatures conducive to the survival and proliferation of Phytophthora cinnamomi. Other features of these growing regions that encourage $P$. cinnamomi infection include ample moisture that coincides with warm soils, in the form of natural rainfall in the southeastern United States or as overhead irrigation in growing operations in northern California. In contrast to the historical predominance of $P$. cinnamomi causing PRR in North Carolina, the current survey detected $P$. taxon kelmania more commonly in this state than $P$. cinnamomi, and also found it to be affecting PRR-tolerant Turkish fir in addition to the commonly affected Fraser fir host. $P$. taxon kelmania is a member of the Phytophthora clade 8a, along with $P$. drechsleri and P. cryptogea, and shares many of the same characteristics of these two including heterothallism, nonpapillate sporangia, and morphological resemblance (Blair et al. 2008; Kroon et al. 2012; Moralejo et al. 2009; Mostowfizadeh-Ghalamfarsa et al. 2010). Although P. drechsleri and P. cryptogea have long been recognized as common PRR species, $P$. taxon kelmania has only been acknowledged by the scientific community since the early 2000 s and is currently being proposed as a novel candidate species (Moralejo et al. 2009). While more intensive sampling of farms in North Carolina would help to substantiate which Phytophthora spp. are currently the most pervasive in this region, the emergence of $P$. taxon kelmania, as well as the detection of others such as $P$. cryptogea and $P$. pini,

Table 2. (continued from preceding page)

\begin{tabular}{|c|c|c|c|c|c|}
\hline Phytophthora spp. & Host & State $^{\mathbf{a}}$ & $N^{\mathbf{b}}$ & Sample $^{c}$ & GenBank $^{d}$ \\
\hline \multirow[t]{6}{*}{ P. cinnamomi } & A. nordmanniana & California & 3 & Root & $\begin{array}{l}\text { KU053226 } \\
\text { KU053227 }\end{array}$ \\
\hline & A. equi-trojani & California & 2 & Root & KU053228 \\
\hline & A. equi-trojani & North Carolina & 2 & Root/Stem & KU220612 \\
\hline & A. concolor & California & 4 & Root & KU053229 \\
\hline & A. bornmuelleriana & North Carolina & 2 & Stem & KU220613 \\
\hline & A. fraseri & North Carolina & 1 & Root & $\mathrm{N} / \mathrm{S}^{*}$ \\
\hline P. cryptogea & A. fraseri & North Carolina & 2 & Stem & KU053246 \\
\hline P. europaea & A. fraseri & Wisconsin & 1 & Collar & $\mathrm{N} / \mathrm{S}^{*}$ \\
\hline P. gonapodyides & A. grandis & Oregon & 2 & Branch & $\begin{array}{l}\text { KU053257 } \\
\text { KU053258 }\end{array}$ \\
\hline \multirow[t]{5}{*}{ P. taxon 'kelmania' } & A. balsamea var. phanerolepis & Wisconsin & 1 & Collar & $\mathrm{N} / \mathrm{S}^{*}$ \\
\hline & A. fraseri & New York & 5 & Root & $\begin{array}{l}\text { KU220615 } \\
\text { KU220616 } \\
\text { KU053242 } \\
\text { KU053244 }\end{array}$ \\
\hline & A. fraseri & Connecticut & 4 & Root & $\begin{array}{l}\text { KU053233 } \\
\text { KU053234 } \\
\text { KU053235 }\end{array}$ \\
\hline & A. bornmuelleriana & North Carolina & 7 & $\begin{array}{l}\text { Root } \\
\text { Stem }\end{array}$ & $\begin{array}{l}\text { KU053247 } \\
\text { KU220614 }\end{array}$ \\
\hline & A. fraseri & North Carolina & 6 & Stem & KU053249 \\
\hline \multirow[t]{3}{*}{ P. megasperma } & A. grandis & Idaho & 2 & Root & $\begin{array}{l}\text { KU053238 } \\
\text { KU053239 }\end{array}$ \\
\hline & A. fraseri & Michigan & 1 & Soil & AY995367* \\
\hline & A. procera & Washington & 2 & Root & $\begin{array}{l}\text { KU053272 } \\
\text { KU053273 }\end{array}$ \\
\hline P. nicotianae & A. fraseri & Michigan & 1 & Soil & AY995347* \\
\hline \multirow[t]{3}{*}{ P. pini } & A. balsamea var. phanerolepis & Connecticut & 1 & Root & KU053230 \\
\hline & A. fraseri & New York & 3 & Root & $\begin{array}{l}\text { KU053240 } \\
\text { KU053241 }\end{array}$ \\
\hline & A. fraseri & North Carolina & 4 & Stem & KU053248 \\
\hline \multirow[t]{3}{*}{ P. plurivora } & A. fraseri & Michigan & 1 & Soil & AY995356* \\
\hline & A. fraseri & Wisconsin & 1 & Collar & N/S* \\
\hline & A. fraseri & Connecticut & 2 & Root & $\begin{array}{l}\text { KU053231 } \\
\text { KU053232 }\end{array}$ \\
\hline P. pseudosyringae & A. fraseri & Washington & 2 & Root & $\begin{array}{l}\text { KU053274 } \\
\text { KU053275 }\end{array}$ \\
\hline \multirow[t]{3}{*}{ P. sansomeana } & A. fraseri & New York & 2 & Root & $\begin{array}{l}\text { KU053243 } \\
\text { KU053245 }\end{array}$ \\
\hline & A. fraseri & Wisconsin & 1 & Collar & $\mathrm{N} / \mathrm{S}^{*}$ \\
\hline & A. fraseri & Michigan & 1 & Soil & AY995366* \\
\hline
\end{tabular}


suggest an increased diversity of PRR-associated Phytophthora spp. in contrast to a landscape historically dominated by P. cinnamomi. $P$. taxon kelmania was also a common member of the PRR communities in the northeastern states of Connecticut and New York, and was received in the collection from Wisconsin, suggesting a geographical derivation from eastern areas. Collections from Abies spp. in the eastern regions indicated more diverse Phytophthora communities in comparison with the western United States, despite being sampled from a relatively narrow host range dominated by Fraser fir. This diversity may again be attributable to a Phytophthora-conducive growing season including summer rainfall, but also to the nationwide circulation of planting stock from an increasing number of nurseries producing Fraser fir seedlings in response to an increased demand for this host species.

The information from this survey has the potential to benefit the growers and purveyors of the conifer seedling and Christmas tree industries by providing valuable information about contemporary host and pathogen ranges, including first reports about new findings. Growers cultivate host species in response to market demands but have also been trying to plant more PRR-tolerant Abies spp. as a cultural method for combatting Phytophthora issues. An ideal solution for avoidance of seedling-borne Phytophthora would be to purchase certified disease-free seedlings for planting; however, the delay between root infestation and the onset of visible foliar symptoms often makes it difficult to ensure that nursery-grown material is free of contamination. Therefore, up-to-date knowledge of the community structure of root-rotting Phytophthora spp. in local areas will assist growers in assessing the risk associated with certain host species substitutions on their farms. Validation of novel host-pathogen combinations and subsequent dissemination of first reports help researchers provide refined expertise to growers and bridge the gap between technical research and public knowledge. The data presented in this article corroborate an underlying concern over a perceived increase in the diversity of Phytophthora spp. in certain regions and inspire questions into the factors that may be contributing to these changes. It is suggested that a current survey of PRR in U.S. conifer nurseries may aid in pinpointing sources of contamination and elucidating channels of Phytophthora spp. distribution on Abies.

\section{Acknowledgments}

We thank the Puget Sound Christmas Tree Growers' Association, the Inland Empire Christmas Tree Growers' Association, the Pacific Northwest Christmas Tree Association, and the cooperating Christmas tree growers in Washington, Oregon, Idaho, California, New York, Connecticut, and North Carolina whose farms were included in the survey; L. Wunderlich at the University of California Central Sierra Cooperative Extension for coordinating visits in California; T. Rathier at the State of Connecticut Agricultural Experiment Station Valley Laboratory for his assistance in coordinating and sampling from Connecticut farms; D. Fulbright from Michigan State University, Department of Plant, Soil, and Microbial Sciences, for supplying archived cultures; A. Phibbs and personnel from the Wisconsin Department of Agriculture Division of Trade and Consumer Protection for supplying cultures; J. Frampton and A. M. Braham from the North Carolina State University Department of Forestry \& Environmental Resources and B. Edwards from the North Carolina State University Cooperative Extension Ashe County Center for sending plant material collected from North Carolina farms; G. Abad for assistance with identification of $P$. taxon kelmania; K. P. Coats for assistance with molecular identifications and phylogenetic analyses; and the Washington State Department of Agriculture Specialty Crop Block Program and the United States Department of Agriculture National Institute of Food and Agriculture Specialty Crop Research Initiative programs for funding this research.

\section{Literature Cited}

Abad, Z. G., Abad, J. A., Cacciola, S. O., Pane, A., Faedda, R., Moralejo, E., PerezSierra, A., Abad-Campos, P., Alvarez-Bernaola, L. A., Bakonyi, J., Jozsa, A., Herrero, M. L., Burgess, T. I., Cunnington, J. H., Smith, I. W., Balci, Y., Blomquist, C., Henricot, B., Denton, G., Spies, C., McLeod, A., Belbahri, L., Cooke, D., Kageyama, K., Uematsu, S., Kurbetli, I., and Degirmenci, K. 2014. Phytophthora niederhauserii sp. nov., a polyphagous species associated with ornamentals, fruit trees and native plants in 13 countries. Mycologia 106:431-447.

Abad, Z. G., Abad, J. A., and Creswell, T. 2002. Advances in the integration of morphological and molecular characterization in Phytophthora genus: The case of $P$. kelmania and other putative new species. (Abstr.) Phytopathology 92:S1
Adams, G. C., and Bielenin, A. 1988. First Report of Phytophthora cactorum and P. citricola causing crown rot of fir species in Michigan. Plant Dis. 72:79.

Benson, D. A., Karsch-Mizrachi, I., Lipman, D. J., Ostell, J., and Sayers, E. W. 2011. GenBank. Nucleic Acids Res. 39:D32-D37.

Benson, D. M., and Grand, L. F. 2000. Incidence of Phytophthora root rot of Fraser fir in North Carolina and sensitivity of isolates of Phytophthora cinnamomi to metalaxyl. Plant Dis. 84:661-664.

Benson, D. M., Grand, L. F., and Suggs, E. G. 1976. Root rot of Fraser fir caused by Phytophthora drechsleri. Plant Dis. Rep. 60:238-240.

Benson, D. M., Grand, L. F., Vernia, C. S., and Gottwald, T. R. 2006. Temporal and spatial epidemiology of Phytophthora root rot in Fraser fir plantations. Plant Dis. 90:1171-1180.

Bienapfl, J. C., and Balci, Y. 2014. Movement of Phytophthora spp. in Maryland's nursery trade. Plant Dis. 98:134-144.

Blair, J. E., Coffey, M. D., Park, S.-Y., Geiser, D. M., and Kang, S. 2008. A multilocus phylogeny for Phytophthora utilizing markers derived from complete genome sequences. Fungal Genet. Biol. 45:266-277.

Brasier, C. 2009. Phytophthora biodiversity: How many Phytophthora species are there? Pages 101-115 in: Phytophthoras in Forests and Natural Ecosystems: Proc. Fourth Meet. Int. Union For. Res. Organ. (IUFRO) Working Party S07.02.09, Monterey, CA. E. M. Goheen and S. J. Frankel, tech. coords. Gen. Tech. Rep. PSW-GTR-221. United States Department of Agriculture Forest Service, Pacific Southwest Research Station, Albany, CA.

Brasier, C. M., Hamm, P. B., and Hansen, E. M. 1993. Cultural characters, protein patterns and unusual mating behavior of Phytophthora gonapodyides isolates from Britain and North America. Mycol. Res. 97:1287-1298.

Campbell, W. A. 1948. Phytophthora cinnamomi associated with the roots of littleleaf-diseased shortleaf pine. Plant Dis. Rep. 32:472.

Chastagner, G. A., and Benson, D. M. 2000. The Christmas tree: Traditions, production, and diseases. Online publication. Plant Health Prog. doi:10.1094/PHP-2000-101301-RV

Chastagner, G. A., Hamm, P. B., and Byther, R. 1990a. Symptomology of Phytophthora root and stem canker disease of noble fir in the Pacific Northwest. (Abstr.) Phytopathology 80:887.

Chastagner, G. A., Hamm, P. B., and Riley, K. L. 1995. Symptoms and Phytophthora spp. associated with root rot of noble fir Christmas trees in the Pacific Northwest. Plant Dis. 79:290-293.

Chastagner, G. A., Riley, K. L., and Hamm, P. B. 1990b. Susceptibility of Abies spp. to seven Phytophthora spp. (Abstr.) Phytopathology 80:887.

Cooke, D. E. L., Drenth, A., Duncan, J. M., Wagels, G., and Brasier, C. M. 2000. A molecular phylogeny of Phytophthora and related oomycetes. Fungal Genet. Biol. 30:17-32.

Cooley, S. J., Hamm, P. B., and Hansen, E. M. 1985. Management Guide to Phytophthora Root Rot in Bareroot Conifer Nurseries of the Pacific Northwest United States Department of Agriculture Forest Service, Pacific Northwest Region, Portland, OR.

Day, W. R. 1938. Root rot of sweet chestnut and beech caused by species of Phytophthora. I. Cause and symptoms of disease: Its relation to soil conditions. Forestry 12:101-116.

Erwin, D. C., and Ribeiro, O. K. 1996. Phytophthora Diseases Worldwide. American Phytopathological Society, St. Paul, MN.

Frampton, J., and Benson, D. M. 2004. Phytophthora root rot mortality in Fraser fir seedlings. HortScience 39:1025-1026.

Frampton, J., and Benson, D. M. 2012. Seedling resistance to Phytophthora cinnamomi in the genus Abies. Ann. For. Sci. 69:805-812.

Garbelotto, M., Huberli, D., and Shaw, D. 2006. First report on an infestation of Phytophthora cinnamomi in natural oak woodlands of California and its differential impact on two native oak species. Plant Dis. 90:685.

Grand, L. F., ed. 1985. North Carolina Plant Disease Index. N. C. Agric. Res. Serv. Tech. Bull. 240. North Carolina Agricultural Experiment Station, Raleigh.

Grand, L. F., and Lapp, N. A. 1974. Phytophthora cinnamomi root rot of Fraser fir in North Carolina. Plant Dis. Rep. 58:318-320.

Hamm, P. B., Cooley, S. J., and Hansen, E. M. 1984. Response of Phytophthora spp. to metalaxyl in forest tree nurseries in the Pacific Northwest. Plant Dis. 68:671-673.

Hamm, P. B., and Hansen, E. M. 1982. Pathogenicity of Phytophthora species to Pacific Northwest conifers. Eur. J. Forest Pathol. 12:167-174.

Hamm, P. B., and Hansen, E. M. 1983. Phytophthora pseudotsugae, a new species causing root rot of Douglas-fir. Can. J. Bot. 61:2626-2631.

Hansen, E. M., Hamm, P. B., Julis, A. J., and Roth, L. F. 1979. Isolation, incidence, and management of Phytophthora in forest tree nurseries in the Pacific Northwest. Plant Dis. Rep. 63:607-611.

Hansen, E. M., Roth, L. F., Hamm, P. B., and Julis, A. J. 1980. Survival, spread, and pathogenicity of Phytophthora spp. on Douglas-fir seedlings planted on forest sites. Phytopathology 70:422-425.

Hansen, E. M., Wilcox, W. F., Reeser, P. W., and Sutton, W. 2009. Phytophthora rosacearum and $P$. sansomeana, new species segregated from the Phytophthora megasperma "complex". Mycologia 101:129-135.

Jeffers, S. N., and Aldwinckle, H. S. 1987. Enhancing detection of Phytophthora cactorum in naturally infested soil. Phytopathology 77:1475-1482.

Jung, T., and Burgess, T. I. 2009. Re-evaluation of Phytophthora citricola isolates from multiple woody hosts in Europe and North America reveals a new species, Phytophthora plurivora sp. nov. Persoonia 22:95-110. 
Jung, T., Nechwatal, J., Cooke, D. E., Hartmann, G., Blaschke, M., Osswald, W. F., Duncan, J. M., and Delatour, C. 2003. Phytophthora pseudosyringae sp. nov., a new species causing root and collar rot of deciduous tree species in Europe. Mycol. Res. 107:772-789.

Kenerley, C. M., and Bruck, R. I. 1981. Phytophthora root rot of balsam fir and Norway spruce in North Carolina. Plant Dis. 65:614-615.

Kroon, L. P. N. M., Brouwer, H., de Cock, A. W. A. M., and Govers, F. 2012. The genus Phytophthora anno 2012. Phytopathology 102:348-364.

Kuhlman, E. G., and Hendrix, F. F., Jr. 1963. Phytophthora root rot of Fraser fir. Plant Dis. Rep. 47:552-553.

Leonberger, A. J., Speers, C., Ruhl, G., Creswell, T., and Beckerman, J. L. 2013. A survey of Phytophthora spp. in Midwest nurseries, greenhouses, and landscapes. Plant Dis. 97:635-640.

Linzer, R., Rizzo, D. M., and Garbelotto, M. 2006. AFLP analysis of Phytophthora nemorosa and $P$. pseudosyringae genetic structure in North America. Pages 149-151 in: Proc. Second Sudden Oak Death Sci. Symp. Monterey, CA. S. J. Frankel, P. J. Shea, and M. I. Haverty, tech coords. Gen. Tech. Rep. PSWGTR-196. United States Department of Agriculture Forest Service, Pacific Southwest Research Station, Albany, CA.

McCain, A. H., and Scharpf, R. F. 1986. Phytophthora shoot blight and canker disease of Abies spp. Plant Dis. 70:1036-1037.

Mehrlich, F. P. 1936. Pathogenicity and variation in Phytophthora species causing heart rot of pineapple plants. Phytopathology 26:23-43.

Mircetich, S. M., and Matheron, M. E. 1976. Phytophthora root and crown rot of cherry trees. Phytopathology 66:549-558.

Moralejo, E., Perez-Sierra, A. M., Alvarez, L. A., Belbahri, L., Lefort, F., and Descals, E. 2009. Multiple alien Phytophthora taxa discovered on diseased ornamental plants in Spain. Plant Pathol. 58:100-110.

Mostowfizadeh-Ghalamfarsa, R., Panabieres, F., Banihashemi, Z., and Cooke, D. E. L. 2010. Phylogenetic relationship of Phytophthora cryptogea Pethybr. and $P$. drechsleri Tucker. Fungal Biol. 114:325-339.

Murphy, S. K., and Rizzo, D. M. 2006. Incidence of Phytophthora ramorum, $P$. nemorosa, and $P$. pseudosyringae in three coastal California forest communities. Pages 69-71 in: Proc. Second Sudden Oak Death Sci. Symp. Monterey, CA. S. J. Frankel, P. J. Shea, and M. I. Haverty, tech coords. Gen. Tech. Rep. PSW-GTR-196. United States Department of Agriculture Forest Service, Pacific Southwest Research Station, Albany, CA.

Newhook, F. J., and Podger, F. D. 1972. The role of Phytophthora cinnamomi in Australian and New Zealand forests. Annu. Rev. Phytopathol. 10:299-326.

Oh, E., and Hansen, E. M. 2007. Histopathology of infection and colonization of susceptible and resistant Port-Orford-cedar by Phytophthora lateralis. Phytopathology 97:684-693.

Park, J., Park, B., Veeraraghavan, N., Jung, K., Lee, Y.-H., Blair, J. E., Geiser, D. M., Isard, S., Mansfield, M. A., Nikolaeva, E., Park, S.-Y., Russo, J., Kim, S. H., Greene, M., Ivors, K. L., Balci, Y., Peiman, M., Erwin, D. C., Coffey, M. D., Rossman, A., Farr, D., Cline, E., Grunwald, N. J., Luster, D. G., Schrandt, J., Martin, F., Ribeiro, O. K., Makalowska, I., and Kang, S. 2008. Phytophthora Database: A forensic database supporting the identification and monitoring of Phytophthora. Plant Dis. 92:966-972.

Parke, J. L., Knaus, B. J., Fieland, V. J., Lewis, C., and Grunwald, N. J. 2014. Phytophthora community structure analyses in Oregon nurseries inform systems approaches to disease management. Phytopathology 104:1052-1062.
Pratt, R. G., Roth, L. F., Hansen, E. M., and Ostrofsky, W. D. 1976. Identity and pathogenicity of species of Phytophthora causing root rot of Douglas-fir in the Pacific Northwest. Phytopathology 66:710-714.

Reeser, P., Sutton, W., and Hansen, E. 2009. Phytophthora species associated with tanoak stem cankers in southwestern Oregon. Pages 87-90 in: Phytophthoras in Forests and Natural Ecosystems: Proc. Fourth Meet. Int. Union For. Res. Organ. (IUFRO) Working Party S07.02.09, Monterey, CA. E. M. Goheen and S. J. Frankel, tech. coords. Gen. Tech. Rep. PSW-GTR-221. United States Department of Agriculture Forest Service, Pacific Southwest Research Station, Albany, CA.

Robideau, G. P., de Cock, A. W. A. M., Coffey, M. D., Hermann, V., Brouwer, H., Bala, K., Chitty, D. W., Désaulniers, N., Eggertson, Q. A., Gachon, C. M., Hu, C.-H., Küpper, F. C., Rintoul, T. L., Sarhan, E., Verstappen, E. C. P., Zhang, Y., Bonants, P. J. M., Ristaino, J. B., and Lévesque, C. A. 2011. DNA barcoding of oomycetes with cytochrome $\mathrm{c}$ oxidase subunit I and internal transcribed spacer. Mol. Ecol. Resour. 11:1002-1011.

Roth, L. F., and Kuhlman, E. G. 1966. Phytophthora cinnamomi, an unlikely threat to Douglas-fir forestry. For. Sci. 12:147-159.

Schwingle, B. W., Smith, J. A., and Blanchette, R. A. 2007. Phytophthora species associated with diseased woody ornamentals in Minnesota nurseries. Plant Dis. 91:97-102.

Shew, H. D., and Benson, D. M. 1981. Fraser fir root rot induced by Phytophthora citricola. Plant Dis. 65:688-689.

Talg $\varnothing$, V., Herrero, M., Toppe, B., Klemsdal, S., and Stensvand, A. 2006. First Report of root rot and stem canker caused by Phytophthora cambivora on noble fir (Abies procera) for bough production in Norway. Plant Dis. 90:682.

Talgø, V., Herrero, M. L., Toppe, B., Klemsdal, S. S., and Stensvand, A. 2007. Phytophthora root rot and stem canker found on Nordmann and subalpine fir in Norwegian Christmas tree plantations.Online publication. Plant Health Prog. doi:10.1094/PHP-2007-0119-01-RS

United States Department of Agriculture National Agricultural Statistics Service. 2014. 2012 Census of Agriculture. United States Summary and State Data, Vol. 1. Geographic Area Series Part 51. Online publication. http://www.agcensus.usda.gov/Publications/2012/Full_Report/Volume_1, Chapter_1_US/usv1.pdf

Vannini, A., and Vettraino, A. M. 2001. Ink disease in chestnuts: Impact on the European chestnut. For. Snow Landscape Res. 76:345-350.

Wager, V. A. 1942. Phytophthora cinnamomi and wet soil in relation to dyingback of avocado trees. Hilgardia 14:517-532.

Wickland, A. C., and Rizzo, D. M. 2006. Ecology of Phytophthora nemorosa and $P$. pseudosyringae in mixed-evergreen forests. Pages 73-75 in: Proc. Second Sudden Oak Death Sci. Symp. Monterey, CA. S. J. Frankel, P. J. Shea, and M. I. Haverty, tech coords. Gen. Tech. Rep. PSW-GTR-196. United States Department of Agriculture Forest Service, Pacific Southwest Research Station, Albany, CA.

Yakabe, L. E., Blomquist, C. L., Thomas, S. L., and MacDonald, J. D. 2009 Identification and frequency of Phytophthora species associated with foliar diseases in California ornamental nurseries. Plant Dis. 93:883-890.

Zentmyer, G. A. 1977. Origin of Phytophthora cinnamomi: Evidence that it is not an indigenous fungus in the Americas. Phytopathology 67:13731377. 